
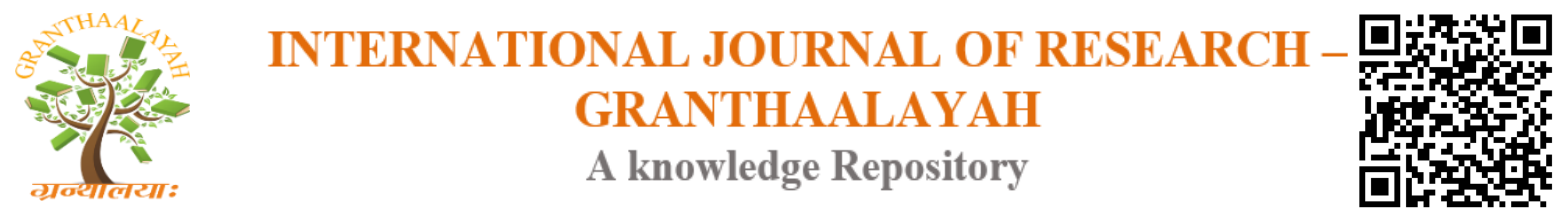

Science

\title{
STUDIES OF DEPRAVED APPETITE IN EGYPTIAN CATTLE
}

Mohamed Saied Mohamed M. *1

${ }^{* 1}$ Ph.D, Veterinarian at GOVS (General Organization of Veterinary Services) in Egypt

\begin{abstract}
The study was carried out on forty-nine (49) cattle cases were clinically healthy animals with average body condition. They were clinically, and laboratory examined proved as healthy cattle and they are free from internal and external parasites were kept as controls while other one hundred (100) cattle animals were suffering from depraved appetites. All animals were belonged to the villages scattered in the Qena Governorate Egypt.

Blood samples were taken from the external jugular vein, and then centrifuged and stored until analyses.

Blood was taken aseptically from all the animals and transported to laboratory for biochemical analysis for estimation of macro and micro elements in diseased animals. Fecal samples was taken aseptically from all the animals and transported to laboratory for the presence of internal parasites. The results showed a highly significant effect of copper, iron, chloride, and sodium significant at $(\mathrm{P}<0.01)$, and low significant of protein, zinc, phosphorus and calcium at $(\mathrm{P}<0.05)$.

The aim of this work was to follow the changes, during the early diagnosis of depraved appetite on some trace elements, protein and internal parasites.

Keywords: Cattle; Depraved Appetite; Trace Elements; Protein; Internal Parasites.

Cite This Article: Mohamed Saied Mohamed M. (2018). "STUDIES OF DEPRAVED APPETITE IN EGYPTIAN CATTLE". International Journal of Research - Granthaalayah, 6(10), 202-211. https://doi.org/10.29121/granthaalayah.v6.i10.2018.1186.
\end{abstract}

\section{Introduction}

Cattle has an economic importance in Egypt, they play a great role in meat, milk and leather production (Taha, 1992).

Cattle in Egypt about 5000,000 in (2009) and 17.3\% of the cattle population and 6\% of the buffalo population are owned by people who do not own agricultural land. $89 \%$ of the cattle population and about $75 \%$ of the buffalo population are in agricultural holdings of less than 2.1 ha.93\% of the cattle population and about $86 \%$ of the buffalo population are in herds of less than ten animals. According to Source: FAO statistics, 2011. Cattle provide the consumers with meat, milk, and their products for fertilizing the lands. 
Livestock form an important component of the agricultural sector, representing about $24.5 \%$ of the agricultural gross domestic product with value of around EGP [Egyptian pounds] 33.6 billion [USD6.1 billion] in 2007 (SADS, 2009). Most number of cows are reared separately in Qena governorate. Most of the farmers have a small number of cows as they are mostly poor and do not really care about health care for their cows veterinary but only when their cows become bad.

Also, the high prices of concentrates led to the peasants to offer diets provide little in quality value or leave their animals beside the canals and rivers to engulf any things. Depraved appetite is a problem facing both the farmers and the veterinarian and veterinarian try to treat the signs. Pica is defined as a depraved appetite or abnormal appetite (Mass 2002) and has been regarded as assigns of nutritional deficiency or boredom (Ralston) 1986 , the condition is seen in cattle (Jain R.K 1994) pregnant and lactating buffaloes (Ranjhan, 1992) camels (Singh et al., 1986) and occasionally in others animals sheep (Sahin and Malik 1986, Akgul et al., 2000), horse (\& (Husted et al. 2005).

Another definition of Pica is a scientific term defining ingestion of nonfood items .it usually refers to pathologic condition in animals that induce compulsive material ingestion, in some cases, material ingestion is simply a behavioral trend, habit or even a normal occurrence.

\section{Materials and Methods}

\subsection{Animals}

Forty-nine_(49) cattle were clinically healthy animals with average body condition They were clinically and laboratory examined proved as healthy cattle and they are free from internal and external parasites were kept as controls. One hundred (100) animals were suffering from depraved. All cattle were subjected to careful clinical examination after method described by (Coles 1986). The animals which were adapted to the veterinary unit by their owners. The complain was a depraved appetite, emaciation, constipations, poor growth., rough hair, and eating a foreign body like plastics, ropes, clothes, metal, bones and breaks.

Classification of animals according to age and sex table (1)

\begin{tabular}{|l|l|l|l|l|l|l|l|l|}
\hline SEX & \multicolumn{2}{|c|}{ Males } & \multicolumn{6}{c|}{ Females } \\
\hline AGE & \multicolumn{2}{|c|}{ 6month-1years } & \multicolumn{2}{c|}{$\mathbf{1 - 3 y e a r s}$} & \multicolumn{2}{c|}{ 3-5years } & \multicolumn{2}{c|}{ Over 5years } \\
\hline & $\begin{array}{c}\text { Controls } \\
\text { animals }\end{array}$ & $\begin{array}{c}\text { depraved } \\
\text { animals }\end{array}$ & $\begin{array}{c}\text { Controls } \\
\text { animals }\end{array}$ & $\begin{array}{c}\text { depraved } \\
\text { animals }\end{array}$ & $\begin{array}{c}\text { Controls } \\
\text { animals }\end{array}$ & $\begin{array}{c}\text { depraved } \\
\text { animals }\end{array}$ & $\begin{array}{c}\text { Controls } \\
\text { animals }\end{array}$ & $\begin{array}{c}\text { depraved } \\
\text { Animals }\end{array}$ \\
\hline No. & 7 & 8 & 14 & 40 & 14 & 28 & 14 & 24 \\
\hline
\end{tabular}

The clinical examination included: Examination of the visible mucous membranes, body temperature, respiratory rates .and also percussion and auscultation of rumen.

\subsection{Collection of Faces}

Fecal sample were collected directly from the rectum of animals in plastics bag and transported to laboratory for examination. Fecal examination carried out by concentration-flotation technique using saturated salt solution of sodium chloride. Samples put in a test tube and then filled with 
saturated solution let it in stand position for 10 minutes. And then uses one drop of supernatant and another from sediment on two separated slides and then examine.

\subsection{Collection of Blood Samples}

Blood samples were collected from each animal under strict hygienic conditions by veinpuncture of jugular vein after the method describe by (Coles 1986). The sample were left in room temperature for 30 minutes and then centrifuge at 3000rpm. The obtained sera were put into sterile, clean, dry vials and kept for biochemical analysis for at -20 degree in deep freeze.

Blood samples were collected for the following determination.

\section{Serum Parameters}

In organic

1) Macro element: calcium $\mathrm{mg} / \mathrm{dl}$ and phosphourous.mg/dl.

2) Micro elements: copper ug/dl., iron ug/dl. and zinc. ug/dl.

Organic: - sodium, and chloride. mol/l. Total protein gm/dl.

\subsection{Postmortum Examination}

A huge amount of unusual foreign bodies collected from the rumen of dead depraved appetite cattle.

\subsection{Statistically Analysis}

The obtained data in the study statistically analyzed by a software program SPSS (statistical package for social science). All the values were expressed as mean \pm standred devation (SD) one way ANOVA applied to compare the results of biochemical values in healthy and depraved cattle.

\section{Results}

\subsection{Clinical Findings}

\section{Skin and Hair Coat}

In the depraved appetite cattle the skin was dry, and a hair coats was rough.

\section{Visible Mucus Membranes}

Paleness of mucus membranes in the depraved appetite cattle were obviously clear in cattle infected with parasites.

\section{Examination of The Rumen}

Auscultation of the rumen showing cessation of rumination, (atony), decrease contraction of rumen by $1-2$ contraction $/ 2$ minutes and typmany. 


\section{Temperatures}

Rectal temperatures ranged between $38.1-38.5 \mathrm{C}^{\circ}$ in depraved appetites cattle.

\section{Clinical Sign}

poor coat, reduced appetite, incoordination weakness, Slow growth, loss of hair, nutritional anemia, pale mucus membranes, decreased weight gains, loss of weight, engulfing a foreign materials such as ropes, plastic, wire, bones, clothes, metals Recently we reported that nonmetallic, soft foreign bodies as plastics could be found in a large probation of cattle (Elmaghraby and Hilat 1997, Al majali etal 1995) photos(1-10) showing these signs.

\subsection{Serum Parameters}

\section{In organic}

1) Macro element: calcium $\mathrm{mg} / \mathrm{dl}$ and phosphourous.mg/dl.

2) Micro elements: copper ug/dl.,iron ug/dl.and zinc. ug/dl.

Organic: - sodium, chloride. mol/l. Total protein gm/dl.

Results of means values \pm SD of biochemical parameters of control and depraved animals

\begin{tabular}{|c|c|c|c|c|c|c|c|c|}
\hline \multirow{3}{*}{$\begin{array}{l}\text { SEX } \\
\text { AGE }\end{array}$} & \multirow{2}{*}{\multicolumn{2}{|c|}{$\begin{array}{r}\text { Males } \\
\text { 6month-1years }\end{array}$}} & \multicolumn{6}{|c|}{ Females } \\
\hline & & & \multicolumn{2}{|c|}{ 1-3years } & \multicolumn{2}{|c|}{ 3-5years } & \multicolumn{2}{|c|}{ Over 5years } \\
\hline & $\begin{array}{l}\text { Control } \\
\text { animals }\end{array}$ & $\begin{array}{c}\text { Depraved } \\
\text { animals }\end{array}$ & $\begin{array}{l}\text { Control } \\
\text { animals }\end{array}$ & $\begin{array}{c}\text { Depraved } \\
\text { animals }\end{array}$ & $\begin{array}{l}\text { Control } \\
\text { animals }\end{array}$ & $\begin{array}{c}\text { Depraved } \\
\text { animals }\end{array}$ & $\begin{array}{l}\text { Control } \\
\text { animals }\end{array}$ & $\begin{array}{l}\text { Depraved } \\
\text { Animals }\end{array}$ \\
\hline No. & 7 & 8 & 14 & 40 & 14 & 28 & 14 & 24 \\
\hline $\begin{array}{l}\text { Calcium } \\
\mathrm{mg} / \mathrm{dl}\end{array}$ & $10.75 \pm 0.1$ & $9.5 \pm 0.2$ & $10.3 \pm 0.3$ & $9.6 \pm 0.4$ & $10.6 \pm 0.1$ & $8.4 \pm 0.2 *$ & $10.2 \pm 0.1$ & $9.2 \pm 0.3$ \\
\hline $\begin{array}{l}\text { phosphorus } \\
\mathrm{mg} / \mathrm{dl}\end{array}$ & $3.4 \pm 0.3$ & $2.5 \pm 0.1 *$ & $3.2 \pm 0.1$ & $2.6 \pm 0.1 *$ & $3.1 \pm 0.2$ & $2.3 \pm 0.1 *$ & $3.1 \pm 0.1$ & $2.1 \pm 0.1 * *$ \\
\hline $\begin{array}{l}\text { copper } \\
\text { ug/dl }\end{array}$ & $139.1 \pm 7.7$ & $75.9 \pm 8.2 * *$ & $133.1 \pm 7.7$ & $80.9 \pm 7.2 * *$ & $135.3 \pm 7.7$ & $85.9 \pm 5.2$ & $131.4 \pm 7.7$ & $88.9 \pm 6.2 * *$ \\
\hline iron ug/dl & $100.8 \pm 0.8$ & $80.5 \pm 3.9 * *$ & $105.8 \pm 0.8$ & $79.5 \pm 3.9 * *$ & $102.8 \pm 0.8$ & $78.5 \pm 3.9 * *$ & $106.8 \pm 0.8$ & $77.5 \pm 3.9 * *$ \\
\hline zinc ug/dl & $87.2 \pm 1.41$ & $77.2 \pm 1.41 *$ & $85.2 \pm 1.41$ & $76.2 \pm 1.11 *$ & $87.2 \pm 1.41$ & $75.2 \pm 1.41 *$ & $87.2 \pm 1.41$ & $78.2 \pm 2.41 *$ \\
\hline $\begin{array}{l}\text { chloride } \\
\mathrm{mmol} / \mathrm{l}\end{array}$ & $140.2 \pm 7.7$ & $75.9 \pm 8.2 * *$ & $133.2 \pm 7.7$ & $80.9 \pm 8.2 * *$ & $135.2 \pm 7.7$ & $73.9 \pm 8.2 * *$ & $132.2 \pm 7.7$ & $78.9 \pm 8.2 * *$ \\
\hline $\begin{array}{l}\text { sodium } \\
\mathrm{mmol} / \mathrm{l}\end{array}$ & $133.5 \pm 0.3$ & $89.9 \pm 3.7 * *$ & $130.5 \pm 0.3$ & $98.9 \pm 3.7 * *$ & $129.5 \pm 0.3$ & $85.9 \pm 3.7 * *$ & $128.5 \pm 0.3$ & $80.9 \pm 3.7 * *$ \\
\hline $\begin{array}{l}\text { Protein } \\
\text { gm/dl. }\end{array}$ & $7.1 \pm 1.2$ & $5.5 \pm 0.2 *$ & $6.1 \pm 1.2$ & $5.1 \pm 0.2 *$ & $6.8 \pm 1.2$ & $5.1 \pm 0.2 *$ & $7.2 \pm 1.2$ & $6.2 \pm 0.2$ \\
\hline
\end{tabular}

Mean \pm SD standered deviation

$*=$ The mean differences is significant at $<0.05$

** The mean difference is significant at $\mathrm{p}<0.01$ 


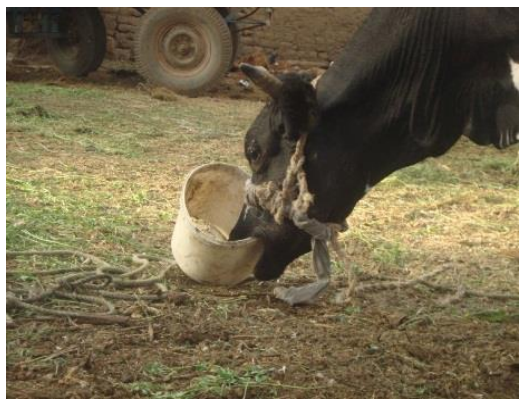

Photo (1) Cattle eating a piece of plastic bucket

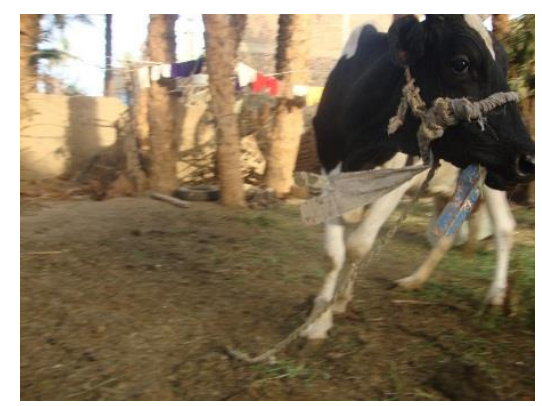

Photo (3) Cattle eating a piece of metal

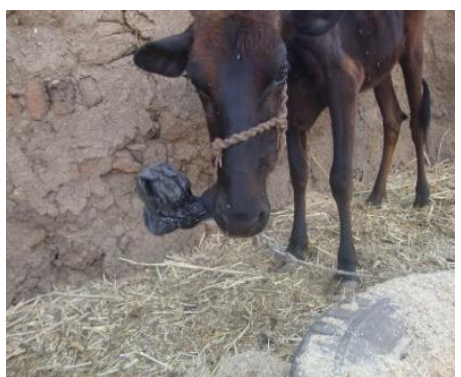

Photo (5) Female cattle eating plastic bag

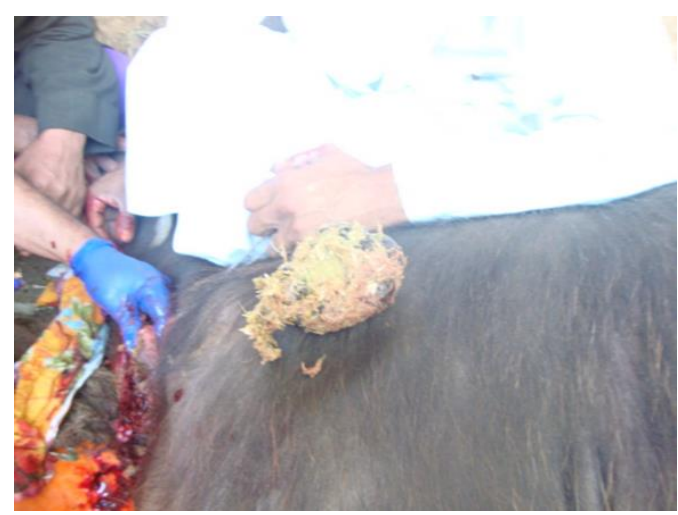

Photo (7) Removal a foreign by surgery

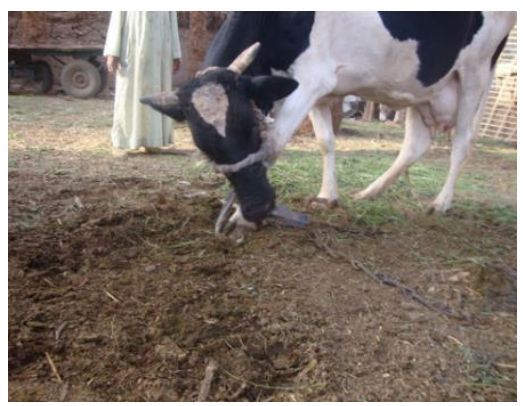

Photo (2) illustrated cattle grazing a piece of metal

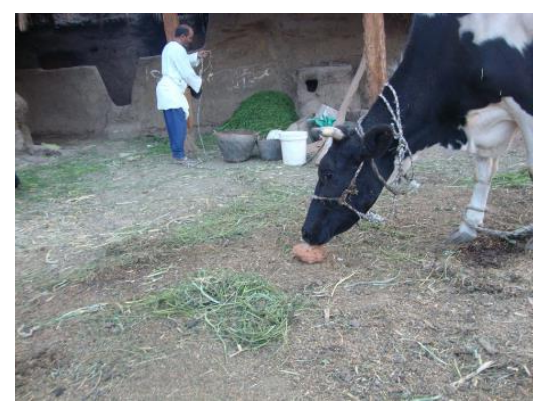

Photo (4) Cattle eating template brick

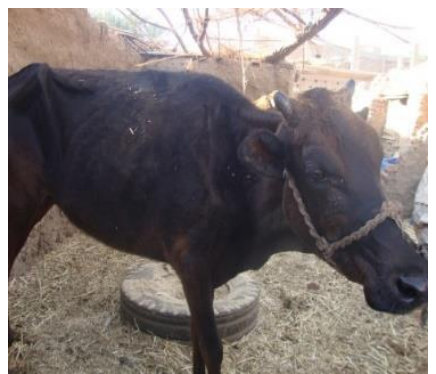

Photo (6) emaciated female cattle

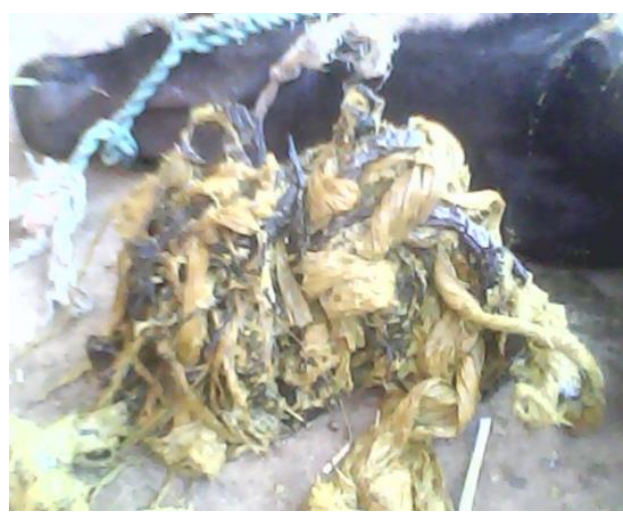

Photo (8) different shape of foreign bodies from male bull 


\subsection{Microscopical Examination}

In this study, revealed that the presence of different types of internal parasites suh as ascris, fasciola, stronglyus and hook worms can cause blood loss, anemia, pica.

\section{Discussion}

\subsection{Clinical Examination}

In this study the depraved appetite constitute a problem facing the owners and the veterinarians. Its e effects appear on decreasing the productivity of the animals meat or milk and, slow growth and poor bone, poor reproductive performance, reduced appetite, incoordination weakness, loss of hair, Nutritional anemia, pale mucus membranes, decreased weight gains, emaciation subsequently on the incomes of the owners further than the cost of treatments and in other hands the poor emaciated animals or the deaths. The reported clinical signs were previously mentioned by (Hussein 2005).

Auscultation of the rumen in abnormal appetite showed cessation of rumination, atony, and decrease contractions of rumen by 1-2contraction /2minutes and typmany. This finding was similar to the observations of (Rao 1987). Hypomotility of rumen may be caused by either a reduction in the excitatory drive to the gastric centers or an increase in inhibitory inputs (Leek, 1969). The temperatures of depraved appetites animals were within normal (Radostits 2007).

\subsection{Biochemical Analysis}

Serum calcium in depraved appetites cattle presents a low significance decreases in males also in females helminth infected and in pregnant. There is no difference between male and female results (Otto. et al, 2001). The animals with depravd appetite in this study showing reduce appetite these agree with (McDowel, 1996). Deficient of calcim in animals cause reduced appetite, loss of gain and low production (Radostitis et al., 2007).

The calcium deficiency may be due to inadequate supply of feeding or mal nutrition or due to age of animal (Doornebal et al. 1988).

The effect of emaciated parasitic animal may lead to decrease of serum calcium in depraved appetite cattle (VanHourt and Sykes 1996, Sadiek, 2001).

Also, the results of serum phosphorus in depraved appetites cattle presents a low significance decrease than controls. There is no significant decrease in serum phosphorus between male and female cattle (Otto et al;2000). In depraved appetite animal infected by helminthes the results revealed significant decrease in phosphorus values than animals without parasitic infestation when compare with controls. (Van Houtert 1996). Also the values are similar in pregnant depraved animals than non pregnant and controls. The tendency to lower P levels in early and late pregnancy compared to the corresponding period in nonmated cows might result from the passing of $\mathrm{P}$ through the placenta and to the negative effect of PTH, which increases urinary P elimination (Chenig et al.1993), (Wallach 2000). The significant decrease of phosphorus may due to nutritional deficiency. 
Zinc serum in depraved male animals are low than control and in female of low significance .and parasitic and pregnancy cattle the values of low significance,

This result is in a partial agreement with that of (Erdogan et al.2004) for cattle and (Yokus and Cakir 2006).

During late pregnancy, the $\mathrm{Zn}$ concentrations were somewhat decreased, but the difference was not significant.

A few reports give the variations of serum $\mathrm{Cu}$ during gestation and lactation (Van Aken et al. 1991).

Serum copper in depraved animals is of high significance decrease in male and in female depraved cattle compared with controls.

Our results on seasonal variations of $\mathrm{Cu}$ are in agreement with some literature reports (Cimtay I and Olculu A, 2000) but not with others (Erdogan and Erdogan 2004). Also, the significant correlation between physiological changes and serum $\mathrm{Cu}$ was observed is consistent with some reports (Cimtay I and Olculu A, 2004) but not others (Vargas et al.1984).

The results values of iron serum in depraved cattle revealed a high significance decrease in depraved animals, especially in pregnant and infested by parasites.

An iron deficiency was also suspected in pica in various animal species, firstly by (Basset et al.1995). The deficiency was due to GI nematodes lead to iron deficiency anemia, which in turn produce growth retardation, stunting and/or poor cognitive development in animal (larrey et al 2006). Diagnostic guidelines were given to explain that deficiency is important to distinguish anemia caused by dietary iron deprivation and that associated with infection or malnutrition. (Green et al. (1993).

The serum values of chloride and sodium in depraved animals revealed a high significance decrease in depraved appetite animals than controls which agree with (Abduallhi et al., 84) who found that causes of allotrophagia is hyponatremia.

Cattle may lick various objects such as rocks, wood, soil and the sweat of other animals. Sometimes, no other visible symptoms occur for months, then appetite begins to decline, the animal subsequently develops an unthrifty appearance with a rough hair coat. This is followed by a rapid loss of body weight and a reduction in milk yield. Eventually, a sudden death will follow a prolonged salt deficiency. (Larry et al. (2006), Total protein level is higher in cows than calves and it is significant. This result agree with the (Roussel et al., 1982 and Doornenbal et al., 1988). In shorthorn cattle (Doornenbal et al., 1988) found except for the values at birth, total protein levels were lower in young animals and higher in mature cattle. (Russell et al., 1982), also found that in Jersey cows total protein increased with age over a range of one to six years. In dairy cattle total protein levels were reported to be higher in dry cows (Peterson et al., 1981). 


\subsection{Microscopical Examination}

The examination of depraved appetite cattle show (70) seventy casses+ve for internal parasites. Heifer infested with ascariasis showed macrocytic hypochromic anemia changed cell parameter, total protein, calcium, inorganic phosphorus. Zinc, copper. (EL.Moghazy, 2011) endoparasite cause significance economic losses and health problems in domestic animals ( Deger et al., 2008)

In general GI nematodes reduce nutrient availability to the host through both reductions involuntary feed intake and/or reductions in the efficiency of absorbed nutrients although the underlying mechanisms of the depression in appetite have not been fully elucidated (Dynes et al., 1998).

\section{Conclusion}

Depraved appetite cattle constitutes a problem that facing the farmers and veterinarian, and this affect animal health and economic value of the animals.

In this study raveled decrease in hematological parameter and serum biochemical parameter of calcium phosphorus, copper, iron, zinc, sodium, chloride, total protein.

\section{Recommendation}

1) The follow up of clinical examination of deprave appetite cattle are very important between the owners and the veterinarians.

2) A repeated parasitic examination of animals. the helminthes parasites are of high important factors that affects the productivity of animal and then affect the hematology and biochemical parameters.

3) Estimation of macro and trace elements help in the treatments of depraved appetite animals.

4) Supply the animals by its requirements from trace elements and balanced ration.

5) Proper housing and managements.

6) Coaching veterinary importance in educating farmers to provide their animals at the beginning of any problem relating to animal health.

7) The return of the insurance system forced the animals from which Walt was giving the owner of the animal concentrates with free intensive veterinary care.

8) Provide courses for farmers through agricultural associations in the best ways to feed the animals and methods of managements.

\section{References}

[1] Abuallahi, U. S. Usman, G.SH, Mchelia, T.A (1984): impaction of rumen with indigestible garbage in cattle and sheep reared win urban and suburban environment Nig. Vei.J. $13: 89-95$.

[2] Akgül Y, Ağaoğlu ZT, Kaya A, Şahin T. (2001): The Relationship Between The Syndromes of Wool eating and Sheep Fed Corn Silage and Blood Changes (Haematological, Biochemical and Trace Elements). Israel Journal of Veterinary Medicine 2001; 56(1): 12-16.

[3] Al majali Wilat. N. Nouh, S, Aladdarr, J.A. Laft, S.Alnif ( 1996 ), prevalence of pathology of foreign body plastic in awassi sheep jordan, small ruminant research . $24: 43-48$. 
[4] Bassett, J. M.; Hanson, C.; Parsons, R.; Wolfensohn, S. E (1995): Anemia in housed newborn lambs. The Veterinary Record, V.11, n. 6, p. 137-140.

[5] Cheng.Y., Goff.J.P., Horst.R.L(1993) : Restoring normal blood phosphorus concentrations in hypophosphatemic cattle with sodium phosphate. Vet Med Cheng Y., 93:383-386.

[6] Cimtay I and A. Olculu, (2000), Investigation on blood plasma and hair copper levels in clinically healthy cattle in Elazig and its vicinity. J. Vet. Anim. Sci. 24, 267-273

[7] Coles, H.E., (1986): Vet. Clinical pathology 4th ed. pp 10-70. w. b Company Philadilipha and London.

[8] Deger, S, Y Deger Aeretkei, Agûl , K, Bicek , and Ozaldal (2008): determination of the status of lipid peroxidation and antioxidant in cattle injected with dictycolus viviparious , turkey parazitol $\operatorname{derg} 32: 234-237$

[9] Doornable H,Tong,A.,K., and Murry N.L.,(1988):Reference values of blood parameter in beef cattle in different age and stages of lactation Can.VET .J.52.99-105.

[10] DoornableH,Tong,A.,K., and Murry N.L.,(1988):Reference values of blood parameter in beef cattle in different age and stages of lactation Can.VET .J.52.99-105.

[11] El- Moghazy F.M., H.A. Shalaby, S. Abdel- Shafy, H.M. Ashry and, (2011): Efficacy of Hydrogen Peroxide and Dihydroxy Benzol Mixture (Disinfectant) on Toxocara canis Eggs. Research Journal of Parasitology, 6: 144-150.

[12] El-magarby H, and Hilat,. N., (2001): Surgical correction of displaced abomasums associated with ruminal and for reticular foreign bodies in cattle. der pkakisch tierazrt $82: 3,201-205$.

[13] Erdogan S, Celik S, Erdogan Z (2004), Sesonal and locational effects on serum, milk, liver and kidney chromium, manganese, copper, zinc, and iron concentrations of dairy cows. Biol. Trace Elem Res 98: 51-61.

[14] Erdogan S, Celik S, Erdogan Z.(2004), Seasonal and locational effects on serum, milk, liver and kidney chromium, manganese, copper, zinc, and iron concentrations of dairy cows. Biol Trace Elem Res. 2004 Apr;98(1):51-61.

[15] Green, L.E., Berriatua, E. and Morgan, K.L. (1993): Anemia in housed lambs. Research in Veterinary Science 54, 306-311.

[16] Hussein,H.A., (2005) :Effects of some internal and external parasitic infestation on body condition in cattle with special reference to liver function tests and some trace elements ,Master Thesis, department of internal Vet. Med., faculty of Vet. Med., Assiut University.

[17] Larry,L, Berger(2006):, Salt and Trace Minerals for Livestock, Poultry and Other Animals.

[18] Leek, B. F. (1969): Reticulo-ruminal function and dysfunction. Vet. Rec.

[19] Mass (2002): Alteration in body weight or size in smith bp (ed) large animal internal medicine 3rd ed. mosby inc st, lousp 170 .3-Ralston SL. Feeding behaviour. Vet Clin North Am. Equine Pract: Behav 1986; 2:609-621.

[20] McDowell, L.R. (1996): Feeding minerals to cattle on pasture. Animal Feed Science and Technology, 60: 247-271.

[21] Outten, C.E. and O'Halloran, T.V. (2001): Femtomolar sensitivity of metallo regulatory proteins controllingzinc homeostasis. Science 292, 2488-2492.

[22] Peterson, R.G., Waldern, D.E. (1981): Repeatabilities of serum constituents in Holstein Friesians affected by feeding, age, lactation and pregnancy. Journal of Dairy Science, 64: 822-831.

[23] Radostits, O. M., Gay, C. C., Blood, D. C. and Hinchcliff, K. W. (2007): Veterinary Medicine A Textbook of the Diseases of Cattle, Sheep, Pigs, Goats and Horses (9th edn.). London: W. B. Saunders Co.

[24] Rao, D. S. T. (1987): Importance of impaction of rumen in bovines. Livestock Advisor 12: 25-26.

[25] Roussel, J.D., Seybt, S.H., Toups, G. (1982): Metabolic profile testing for Jersey cows in Louisiana: Reference Values. American Journal of Veterinary research, 43:1075-1077.

[26] Roussel, J.D., Seybt, S.H., Toups, G. (1982): Metabolic profile testing for Jersey cows in Louisiana: Reference Values. American Journal of Veterinary research, 43:1075-1077. 
[27] Sadiek,A.,H., (2001):Emaciation and ill thrift in sheep and goats in New Valley Gover. 6th Sci. Congress of cattle Diseases NOV.2001.

[28] Sustainable Agricultural Development Strategy Towards 2030 (SADS). 2009. Agricultural Research \& Development Council. Arab Republic of Egypt, Ministry of Agriculture \& Land Reclamation. Oct. 2009.

[29] Taha,A.M.(1991):Clinical,hematological and immunological studies on parasitic anemia of cattle ,M.V.Sci.Thesis (infectious Disaeses),Department of Animal Medicine, Faculty of Veterinary Medicine,Assiut University.

[30] Van D Aken, Jde,Bont,L,Van Holms and S.S.E.Ranwana(1991), A study on mineral status of cattle in a dairy farm in Sri Lanka .Indian Vet. J. 68, 371-374.

[31] Van D Aken, Jde,Bont,L,Van Holms and S.S.E.Ranwana (1991), A study on mineral status of cattle in a dairy farm in Sri Lanka Indian Vet. J. 68, 371-374.

[32] Van Hourt M.F.J. and Sykes, A.R. (1996): Implication of nutration for the ability of ruminants to with stand gastrointestinal nematode.Int. J. Parasitology.26,1151-1167.

[33] Vargas D. R., L. R. McDowell, J. H. Conrad, F. G. Martin, C. Buergelt, and G.L.Ellis,(1980):The mineral status of cattle in Colombia as related to a wasting disease ("secadera"), Trop. Anim. Prod. 9, 103-113.

[34] Wallach J., (2000): Interpretation of Diagnostic Tests, 7th ed., Lippincott Williams\& Wilkins, Philadelphia.

[35] Yocus Beran and Ulcker Dielk Cakir(2006) :Seasonal and physiological variation in serum chemistry and mineral concentration in cattle., Biological Trace Element Research Vol. 109, 2006.

\footnotetext{
*Corresponding author.

E-mail address: mosmvet@yahoo.com
} 